\title{
Erratum to: Efficacy of cleaning tablets for removable orthodontic appliances. An in vivo pilot study
}

\author{
P.-G. Jost-Brinkmann
}

In this article, the first name for Hywa Fathi was incorrect.

Readers are asked to note the correct name and we apologize for the error.

The editorial team
In diesem Beitrag wurde der Vorname von Hywa Fathi falsch angegeben.

Wir bitten, die korrekte Nennung zu beachten und den Fehler zu entschuldigen.

Die Redaktion

\section{Correspondence Address}

Prof. Dr. P.-G. Jost-Brinkmann

Department of Orthodontics, Dentofacial Orthopedics and Pedodontics, Charité - Universitätsmedizin Berlin, CC3, Center for Dental and Craniofacial Sciences

Aßmannshauser Str. 4-6, 14197 Berlin

paul-g.jost-brinkmann@charite.de
Department of Orthodontics, Dentofacial Orthopedics and Pedodontics, Charité - Universitätsmedizin Berlin, CC3, Center for Dental and Craniofacial Sciences, Berlin

published online: 20 May 2015
The online version of the original article can be found at: $\mathrm{http}: / / \mathrm{dx}$. doi.org/10.1007/s00056-014-0277-x 